$12-1-2019$

\title{
Smallmouth Bass Population Demographics in Missouri Ozark Streams and an Evaluation of a Statewide 305-mm Minimum Length Limit
}

Edward M. Sterling

Kylie B. Sterling

Quinton E. Phelps

Missouri State University

Tyler D. Ham

Sara J. Tripp

Follow this and additional works at: https://bearworks.missouristate.edu/articles-cnas

\section{Recommended Citation}

Sterling, Edward M., Kylie B. Sterling, Quinton E. Phelps, Tyler D. Ham, and Sara J. Tripp. "Smallmouth Bass Population Demographics in Missouri Ozark Streams and an Evaluation of a Statewide 305-mm Minimum Length Limit." North American Journal of Fisheries Management 39, no. 6 (2019): 1175-1191.

This article or document was made available through BearWorks, the institutional repository of Missouri State University. The work contained in it may be protected by copyright and require permission of the copyright holder for reuse or redistribution.

For more information, please contact BearWorks@library.missouristate.edu. 


\title{
ARTICLE
}

\section{Smallmouth Bass Population Demographics in Missouri Ozark Streams and an Evaluation of a Statewide 305-mm Minimum Length Limit}

\author{
Edward M. Sterling* \\ U.S. Fish and Wildlife Service, 101 Park Deville Drive, Columbia, Missouri 65203, USA
}

Kylie B. Sterling

Department of Biology, College of the Ozarks, 100 Opportunity Avenue, Point Lookout, Missouri 65726, USA

Quinton E. Phelps

Department of Biology, Missouri State University, Springfield, Missouri 65897, USA

Tyler D. Ham

Indiana Department of Natural Resources, 2310 East SR364, Winslow, Indiana 47598, USA

Sara J. Tripp

Missouri Department of Conservation, 2302 County Park Drive, Cape Girardeau, Missouri 63701, USA

\begin{abstract}
The Ozark streams of Missouri provide anglers with unique Smallmouth Bass Micropterus dolomieu fishing opportunities. To ensure the sustainability and potential of these fisheries, we sampled five streams in the Ozark highland ecoregion of southern Missouri via recreational angling methods. From our samples, we developed estimates of recruitment, growth, and mortality, and assessed current regulations for Smallmouth Bass. To accomplish these objectives, we aged otoliths from 75 legal $(305-\mathrm{mm})$ fish on each stream. Back-calculated length-at-age estimates were formed for sublegal lengths, and were paired with electrofishing length distributions on each stream using an agelength key. These data were used to develop estimates of dynamic rate functions and models of yield, spawning potential, and number of memorable fish for each study population. We found that recruitment was stable on each stream, but growth and mortality varied among streams. We also found that models of yield, spawning potential, and number of memorable fish varied greatly among streams. Our results showed that the current 305-mm statewide minimum length limit is applicable for some of our study streams, but yield, spawning potential, and trophy potential could increase with more restrictive length limits on some of our study streams. More spatially explicit length limits can help these Smallmouth Bass populations reach their growth potential. This information can help inform stream management in Missouri and across the Ozark region of the Midwest.
\end{abstract}

Dynamic rate functions of recruitment, growth, and mortality are factors that can drive shifts in populations over time. Recruitment is the survival of an organism to a given reference point in its life cycle
(Chambers and Trippel 1997). Growth is characterized by the rate at which an organism within a population develops size (Beamesderfer and North 1995). Mortality is the number of deaths in a population over a given

*Corresponding author: edward_sterling@fws.gov

Received March 11, 2019; accepted August 15, 2019 
amount of time. Recruitment, growth, and mortality are susceptible to change over time due to a variety of biotic (e.g., genetic variability, food availability, invasive species) and abiotic (e.g., temperature, climatic variability) factors that can affect populations within a given ecosystem (Beverton and Holt 1957; Sissenwine 1984). Evaluation of dynamic rate functions in populations across a spatial gradient can help inform effective management. Proper evaluations can provide critical population-level information, allowing managers to predict factors (e.g., harvest) that may be affecting populations while formulating regulations that best suit each population. Evaluations are particularly necessary for popular sportfish populations.

Sportfishing is an economically and recreationally important activity throughout North America (USFWS 2011). High economic value gives credence for sportfish management efforts, particularly for members of the family Centrarchidae (Cooke and Philipp 2009). Smallmouth Bass Micropterus dolomieu is a highly sought-after sportfish species throughout Missouri and the rest of the United States, and is tolerant of diverse habitats ranging from large reservoirs to small streams, including streams in the Ozark Highland ecoregion, hereafter referred to as the "Ozarks" (MacCrimmon and Robbins 1975). Smallmouth Bass have been studied extensively within Missouri (Pflieger 1966; Matthews 1982; Probst et al. 1984; Williamson et al. 2015), but little is known regarding dynamic rate estimates and the resulting management strategies for Smallmouth Bass in the Ozarks.

Many Ozark streams exhibit unique physical and chemical characteristics (e.g., spring influence) that could affect populations of Smallmouth Bass (Lohman et al. 1991; Whitledge and Rabeni 2000). Smallmouth Bass also naturally exhibit slower growth than other Micropterus species (Beamesderfer and North 1995). Slow growth and other natural differences between populations of Ozark stream Smallmouth Bass could be further compounded by genetic differences between populations. This is likely due to previous Ozark stream stocking efforts (Funk and Fleener 1974; Stark and Echelle 1998) of its subspecies, the Northern Smallmouth Bass M.dolomieu dolomieu and the Neosho Smallmouth Bass M.d. velox, intergrading in the southern Ozark streams of Missouri. Nonnative allele introduction could pose complex genetic variability among populations of Smallmouth Bass in this region (Brewer and Orth 2015). Growth differences have been observed between genetically distinct populations of Smallmouth Bass (Brewer and Long 2015). Variable growth due to genetics coupled with slow growth, varying habitat characteristics, and potentially high harvest could lead to overexploitation. It is important that managers have baseline information on the age and growth of different Smallmouth Bass populations within the Ozark Highlands so that we can improve our understanding of the various pressures (i.e., diverse habitats, genetics, harvest) that could influence population parameters.

Reliable estimates of age are necessary for assessing a population's vital rates. Fishery scientists have historically used scales, fin rays, and otoliths to derive age estimates (DeVries and Frie 1996). Although scales have predominantly been used to age centrarchid species, many studies depict the error associated with using this method (Prather 1967; Hammers and Miranda 1991; Long and Fisher 2001; Rude et al. 2013). Although removal of otoliths is lethal, they have been validated for determining the age of Smallmouth Bass (Heidinger and Clodfelter 1987). Using a reliable aging structure is necessary for providing precise age estimates that offer dependable assessments of dynamic rate functions within a population.

Reliable estimates of recruitment, growth, and mortality within populations of Smallmouth Bass can be used to simulate the response of these populations to varying levels of exploitation. With the possibility of overexploiting this species, modeling various harvest scenarios and projected changes in populations due to harvest rates will allow managers to understand how exploitation can affect yield, reproductive potential, and the trophy potential for these populations. Two types of overexploitation can be observed in a recreational fishery: growth overfishing and recruitment overfishing. Growth overfishing occurs when anglers are removing fish from a population at such a rate that growth and yield potentials cannot be maximized (Colombo etal. 2007). Recruitment overfishing occurs when individuals are being removed from a population faster than they can be replaced by reproduction (Dotson et al. 2009). Yield-per-recruit (YPR) models and spawning-potential-ratio (SPR) models are common tools used to assess growth and recruitment overfishing. These models have been used to effectively assess sportfish populations (Goodyear 1993; Slipke et al. 2002; Bueltmann and Phelps 2015).

The objective of this study was to estimate recruitment, growth, and mortality of five intergrade populations of Ozark stream Smallmouth Bass in southern Missouri and to evaluate the relationship between different harvest rates and minimum length limits. With a better understanding of vital rates, we can build upon existing information to help ensure sustainable, quality Smallmouth Bass fisheries throughout the Ozark Highlands.

\section{METHODS}

Study areas.-Five southern Missouri Ozark streams were selected as study sites: Castor River, Black River, Courtois Creek, Current River, and North Fork of the White River (Figure 1). These rivers were chosen based on their relatively high angler use across all Ozark 
streams (Williamson et al. 2015). These rivers are all inhabited by intergrade Smallmouth Bass populations and are likely representative of other systems with intergrade populations. The Castor River is a sixth-order stream, originating in Ste. Genevieve County, Missouri, flowing south for $111 \mathrm{~km}$, emptying into the Headwater Diversion Channel and ultimately into the Mississippi River near Cape Girardeau, Missouri (Norman 1994). The Castor River is wadeable throughout much of its course, maintaining stable base flows. The Black River is a seventh-order stream flowing south from Reynolds County, Missouri, for approximately $40 \mathrm{~km}$ before emptying into Clearwater Lake (Cieslewicz 2004). It is wadeable on the upper portions and accessible by jet boat just before emptying into Clearwater Lake. The Black River is set apart by warmwater influence from a hydropower plant near Lesterville, Missouri. The Courtois Creek is a relatively small fifth-order stream in the Meramec River drainage that flows north for $61 \mathrm{~km}$ and drains into the Huzzah River in Crawford County, Missouri (Blanc et al. 1998). This stream is wadeable throughout most of its course with only a few deep holes $(>2 \mathrm{~m})$. The Current River is a large seventh-order stream, running south for $296 \mathrm{~km}$ from Dent County, Missouri, and emptying into the lower Black River in Arkansas. The Current River is accessible by jet boat throughout most of its course, and is defined by a large amount of coldwater spring influence (Jacobson and Gran 1999; Wilkerson 2003). The North Fork of the White River is a relatively small seventh-order stream that flows south for $107 \mathrm{~km}$ from Wright County, Missouri, and empties into the Norfork

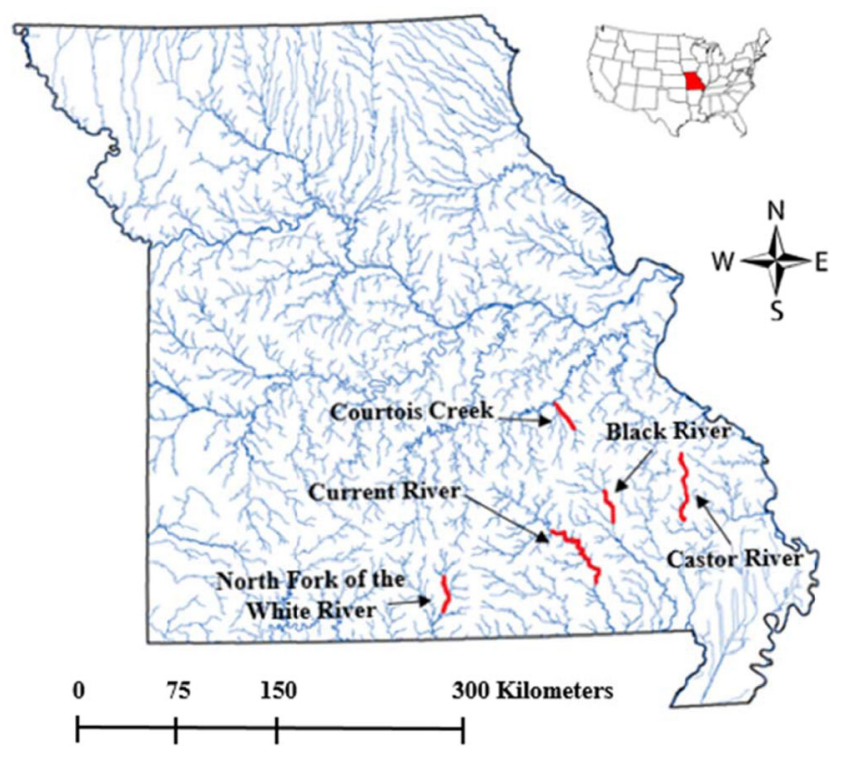

FIGURE 1. A map of Missouri, showing the streams throughout the state. The stream sample sites are highlighted. [Color figure can be viewed at afsjournals.org.] reservoir in Arkansas. The North Fork of the White River is wadeable throughout most of its course and is characterized by heavy coldwater spring influence (Miller and Wilkerson 2001). The North Fork of the White River is also home to nonnative trout species that are stocked on a yearly basis. The geological boundaries of these streams isolate populations of fish within watersheds, allowing each system to be managed on an individual basis (Pflieger 1971). The varying physical and chemical characteristics of these streams help to provide the platform for developing spatially explicit models for each population.

Collection methods.-We collected 75 specimens for aging that had a TL of greater than $305 \mathrm{~mm}$ from each study system. This was accomplished via legal angling from May 28, 2016 through October 31, 2017. We used previously collected length frequency and tagging data from each of these streams that were collected by the Missouri Department of Conservation via spring electrofishing in 2011 and 2013. The 2011 and 2013 samples were in conjunction with a harvest evaluation utilizing reward tags (Pollock et al. 2001). The fish were tagged before open harvest season in Missouri, which begins at the end of May each year. Harvest estimates were developed from cumulative monthly exploitation estimates from tag returns (Williamson et al. 2015).

Sample processing.-A target sample size of 75 specimens $(>305 \mathrm{~mm})$ were harvested from each of the five study streams to give an adequate representation of each river's population. Seventy-five samples allowed us to collect at least 10 samples per available $25-\mathrm{mm}$ length class. Specimens were measured (as TL in $\mathrm{mm}$ ), weighed (g), and sexed via internal examination. The sagittal otoliths were removed (Graham and Orth 1986), and the ovaries from females were removed and frozen for fecundity estimates.

After collection, the otoliths were dried and aged by use of two independent readers for precision. Each otolith was submerged in glycerol and viewed whole beneath a dissecting microscope with low magnification (6-50×). Any otoliths that appeared to have annuli crowded at the margins or were unclear were fractured on the transverse plane, mounted in clay, submerged in glycerol, and viewed using illumination from a fiber optic light (Buckmeier and Howells 2003). If there was disagreement on the age of a particular specimen, those conducting the aging reviewed the otoliths until a consensus was reached (Maceina and Sammons 2006).

Data analyses. - With only legal-sized Smallmouth Bass being used for aging, linear back-calculation of the otoliths was used to provide estimates of sizes and ages of sublegal fish (Weisberg 1986). Back-calculated length-at-age of other centrarchid species using sagittal otoliths has been shown to be reliable (Frie 1982; Taubert and Tranquilli 
1982; Hales and Belk 1992; Wahl et al. 2009). Utilizing a 10-mm age-length key in the Fishery Analysis and Modeling Simulator (FAMS; American Fisheries Society), backcalculated length-at-age estimates were paired with length frequency data from the 2011 and 2013 electrofishing surveys to assign ages to un-aged fish (Slipke and Maceina 2014). All following analyses were performed on the paired angling and electrofishing data.

Recruitment. - We calculated the recruitment variability index (RVI) for each Smallmouth Bass population to assess relative recruitment stability (Guy and Willis 1995). The index is defined as

$$
\mathrm{RVI}=\left(\frac{S_{N}}{N_{m}+N_{p}}\right)-\frac{N_{m}}{N_{p}},
$$

where $S_{N}$ represents cumulative relative frequencies across year-classes in the sample, $N_{m}$ is the number of yearclasses missing from the sample, and $N_{p}$ is the number of year-classes present in the sample. Variability index values can range from -1 to 1 , with values closer to 1 representing relatively stable recruitment (Guy and Willis 1995; Isermann etal. 2002). From this model, the status of selected Smallmouth Bass populations could be evaluated to determine if the populations had stable recruitment.

Growth.-Growth was calculated by use of the von Bertalanffy growth equation available in FAMS (Von Bertalanffy 1938). The von Bertalanffy equation is defined as

$$
L_{t}=L_{\infty}\left[1-e^{-K\left(t-t_{0}\right)}\right],
$$

where $L_{t}$ is the average length at time $t, L_{\infty}$ is the theoretical maximum length, $K$ is the Brody growth coefficient, or rate at which the fish reaches $L_{\infty}$, and $t_{0}$ is the length at time zero. The von Bertalanffy growth equation takes the average length-at-age into consideration to determine the theoretical maximum length and the rate at which a fish population reaches that length.

Mortality.-To determine mortality rates in each population, a catch-curve method was used in FAMS (Ricker 1973; Maceina 1997; Hubert and Quist 2010). This method assumes equal catch rates among fish across the population. Given that electrofishing appeared to be size-selective, we used the peak year classes and subsequent year classes for our analyses, assuming that these cohorts had fully recruited to the gear used (Chapman and Robson 1960; Robson and Chapman 1961). The catch-curve equation is defined as

$$
A M=1-\left(e^{-z}\right),
$$

where $A M$ is total annual mortality, and $z$ is instantaneous mortality.
After procuring estimates of dynamic rate functions, these estimates were used in FAMS to build models predicting the potential effects of management strategies. We used our data to analyze the effects of varying length limits on each population. Our models provided estimates of how each population would respond (yield, reproductive potential, number of memorable sized fish: Gabelhouse 1984) to varying exploitation rates under a spectrum of minimum length limits (MLL; e.g., 305, 330, 355, 381, $406 \mathrm{~mm}$ ). This allowed us to predict if each population had the propensity to succumb to the effects of recruitment and/or growth overfishing under current management strategies and more restrictive length limits.

Yield-per-recruit.- In order to assess yield and growth overfishing, we implemented a Beverton and Holt yieldper-recruit model (1957). The model can be expressed as

$$
\frac{Y}{R}=F W_{\infty}\left(\frac{1}{Z}-\frac{3 e^{-k r_{1}}}{Z+K}+\frac{3 e^{-2 k r_{1}}}{Z+2 K}-\frac{e^{-3 k r_{1}}}{Z+3 K}\right),
$$

where $Z$ is the sum of $F$ and $M$, which are the instantaneous rates of total fishing and natural mortality, respectively; $r_{1}=t_{e}-t_{0} ; W$ is weight, and $K$ and $t_{0}$ are the parameters of the von Bertalanffy growth equation (Beverton and Holt 1957). Growth overfishing was indicated by a descending limb in the YPR model.

Spawning potential ratio.- The model of SPR is derived by estimating the actual lifetime production of mature eggs per recruit $(P)$ at an equilibrium population density in the absence of any density-dependent suppression of maturation or fecundity (Goodyear 1993). We used egg counts from the ovaries that were extracted from each female to obtain measures of fecundity. Age at sexual maturation was determined to be the youngest female with eggs. Any ovary that was deemed undeveloped via visual inspection, or collected postspawn, was disregarded for the analysis. The youngest female in which sexual maturity was observed was 3 years old. All females at 4 years of age were found to be sexually mature. We used a rate of $50 \%$ to represent the percentage of females spawning between 3 and 4 years of age and a rate of $100 \%$ for subsequent ages. The equation for spawning potential ratio is as follows:

$$
P=\sum_{i=1}^{n} E_{i} \prod_{j=0}^{i=1} S_{i j}
$$

where $n$ is the number of ages in the population, $E_{i}$ is mean fecundity of females of age $i$ in the absence of density-dependent growth; $S_{i j}=\left[-\left(F_{i j}+M_{i j}\right)\right]=$ the densityindependent annual survival probabilities of females of age $i$ when age $j ; F_{i j}=$ the fishing mortality rate of females of age $i$ when age $j$; and $M_{i j}=$ the natural mortality rate 
of females of age $i$ when age $j$. The SPR is calculated as

$$
\mathrm{SPR}=\frac{P_{\text {fished }}}{P_{\text {unfished }}},
$$

where $P$ (the potential recruit fecundity) represents the number of mature eggs that could be produced by an average recruit in a fished and unfished population. The SPR has a maximum value of 1.00 when no harvest occurs and declines toward zero as mortality increases (Slipke et al. 2002). Recruitment overfishing was indicated when the SPR value dropped below 20\%. The SPR value of $20 \%$ represents a conservative estimate of reproductive potential necessary to maintain a resilient fish population such as Smallmouth Bass (Slipke et al. 2002).

Model of memorable size.-Models of number of memorable-sized Smallmouth Bass were developed in FAMS as well. These models helped to visualize how many memorable-sized Smallmouth Bass $(\geq 430 \mathrm{~mm})$ each population could produce under various minimum length limits and exploitation estimates. Growth parameters and natural mortality rates were used in these models to predict theoretical numbers of $430 \mathrm{~mm}$ Smallmouth Bass in each population (Slipke and Maceina 2014).

\section{RESULTS}

In total, 4,991 Smallmouth Bass were sampled by the Missouri Department of Conservation via electrofishing in 2011 and 2013. Counts from each river were as follows: 557 from the Black River, 1,343 from the Castor River, 1,506 from the Current River, 1,062 from the Courtois Creek, and 523 from the North Fork of the White River. Length frequency distributions were similar among streams, with more fish being sampled from the Current and Castor rivers (Figure 2). Mean lengths varied somewhat across streams (Appendix Table A.1). In 2016 and 2017, 367 Smallmouth Bass were collected via angling (75 from the Castor River, 74 from the Black River, 67 from the Courtois Creek, 75 from the Current River, and 76 from the North Fork of the White River; Table A.2). Mean lengths were similar among sample streams with only fish greater than $305 \mathrm{~mm}$ being sampled (Table 1). Age-length distributions, estimated from the back-calculation analyses, depict a right skew for the Black River, Castor River, Current River, and Courtois Creek, and a platykurtic distribution for the North Fork of the White River (Figure 3).

\section{Recruitment}

Recruitment was similar among the five streams we evaluated. The RVI values ranged from 0.69391 on the North Fork of the White River to 0.76440 on the Courtois Creek (Table 1).

\section{Growth}

Mean length-at-age varied between stream systems, with the Black River depicting relatively fast growth compared with other streams and the North Fork of the White River depicting relatively slow growth (Table 2). The von Bertalanffy growth coefficients varied among each study stream as well (Figure 4). The theoretical maximum length $\left(L_{\infty}\right)$ differed over $100 \mathrm{~mm}$ between streams. The Castor River had the highest $L_{\infty}$ $(662 \mathrm{~mm})$, and the North Fork of the White River had the lowest $(551 \mathrm{~mm}$; Table 1$)$. The Brody growth coefficient $(K)$, or rate at which an individual reaches the theoretical maximum length, was highest on the Courtois Creek at 0.150, and lowest on the Castor River at 0.107 (Table 1).

\section{Mortality}

Catch-curve analyses showed that mortality estimates ranged from $49 \%$ to $60 \%$ total annual mortality (Figure 5). The total annual mortality was greatest on the Black River at $60 \%$, and lowest on the Courtois Creek at $49 \%$ (Table 1).

\section{Yield-per-Recruit}

Overall, YPR models estimated that with the 305$\mathrm{mm}$ MLL, each stream could be affected by growth overfishing under high exploitation rates, with the exception of the North Fork of the White River (Figure 6). On the Black River, growth overfishing is shown to occur under a $305-\mathrm{mm}$ MLL at exploitation rates exceeding 30\%, under a 330-mm MLL at exploitation rates exceeding $50 \%$, and under a $355-\mathrm{mm}$ MLL at exploitation rates exceeding 75\%. Conversely, on the North Fork of the White River, the 305-mm MLL provided the highest angler yield potentials under all exploitation rates.

\section{Spawning Potential Ratio}

Similarly, the SPR models showed that with the 305mm MLL, each stream could be affected by recruitment overfishing under high exploitation rates, with the exception of the North Fork of the White River (Figure 7). On the Black River, recruitment overfishing occurred under the $305-\mathrm{mm}$ MLL at exploitation rates exceeding $40 \%$ and under the 330-mm MLL at exploitation rates exceeding $60 \%$. However, the North Fork of the White River did not exhibit recruitment overfishing under any MLL, or under high exploitation rates.

\section{Model of Memorable Size}

The models of memorable-sized Smallmouth Bass (i.e., $\geq 430 \mathrm{~mm}$ ) depicted an increase in their numbers in each stream under more restrictive length limits (Figure 8). The Black River showed that under exploitation 

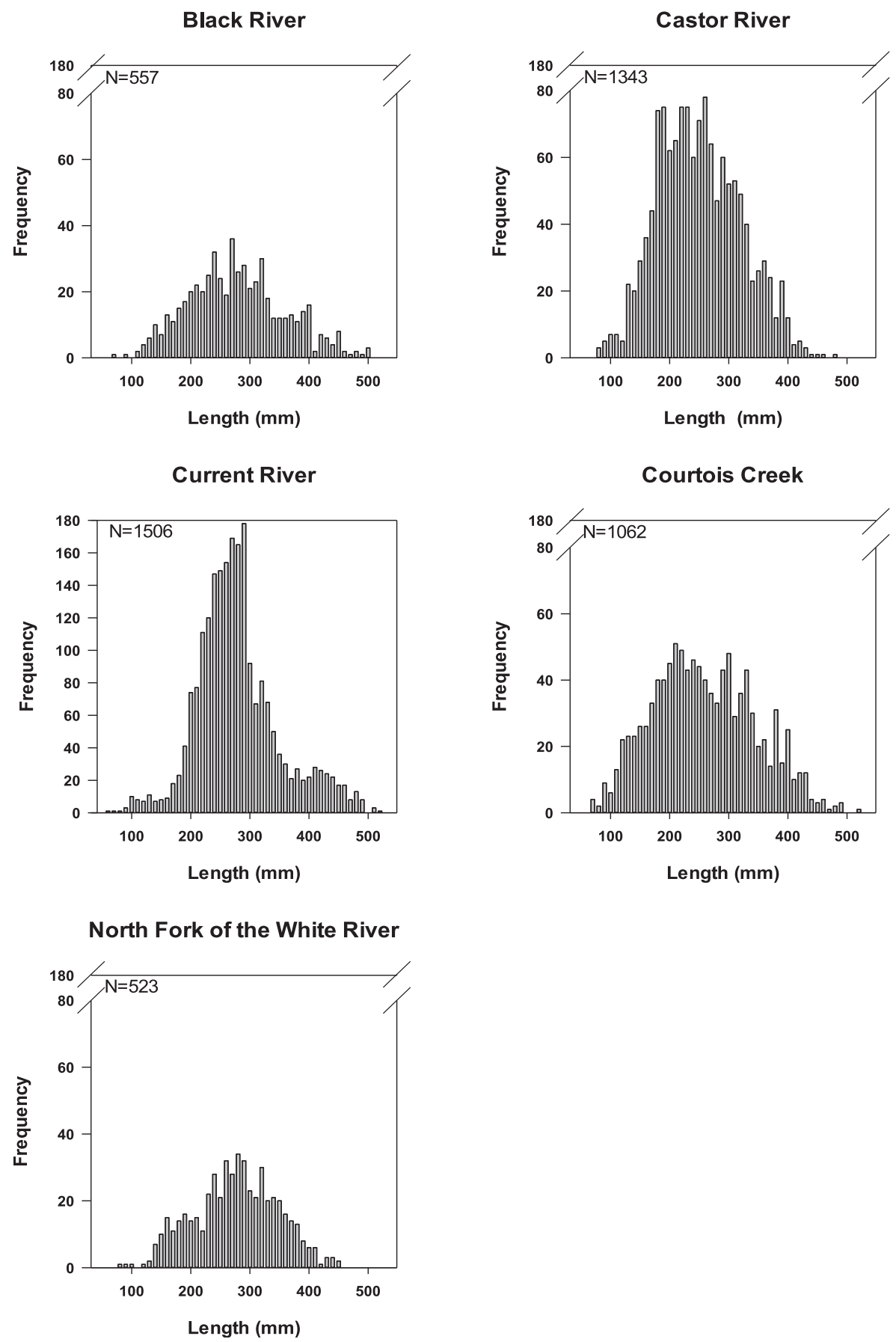

FIGURE 2. Smallmouth Bass TL (mm) frequency distributions for each study stream from the 2011-2013 electrofishing data.

rates of $20-40 \%$, a $381-\mathrm{mm}$ MLL could produce over 40 more memorable-sized individuals per 1,000 recruits when compared with a $305-\mathrm{mm}$ MLL. Conversely, the North Fork of the White River showed that under the same exploitation rates, a 381-mm MLL would produce only 10 more memorable-sized individuals per 1,000 recruits when compared with a 305-mm MLL.

\section{DISCUSSION}

Our results suggest that Smallmouth Bass dynamic rates vary among streams in the Ozark region of Missouri. These variations in recruitment, growth, and mortality produced differences in our models of yield, spawning potential, and number of memorable-sized fish in each of our study streams. The differences that we observed in our 
TABLE 1. Life history parameters of Smallmouth Bass in each study stream; RVI are recruitment variability index values, $L, K$, and $t_{0}$ are von Bertalanffy Growth coefficients, and AM is the total annual mortality.

\begin{tabular}{|c|c|c|c|c|c|}
\hline Parameters & Castor River & Black River & $\begin{array}{l}\text { Current } \\
\text { River }\end{array}$ & $\begin{array}{l}\text { Courtois } \\
\text { Creek }\end{array}$ & $\begin{array}{c}\text { North Fork } \\
\text { of the White } \\
\text { River }\end{array}$ \\
\hline RVI & 0.70181 & 0.74955 & 0.74951 & 0.76440 & 0.69391 \\
\hline$L_{\infty}$ & $662 \mathrm{~mm}$ & $645 \mathrm{~mm}$ & $563 \mathrm{~mm}$ & $602 \mathrm{~mm}$ & $551 \mathrm{~mm}$ \\
\hline$K$ & 0.107 & 0.129 & 0.142 & 0.15 & 0.143 \\
\hline$t_{0}$ & -1.108 & -1.183 & -1.484 & -0.868 & -0.534 \\
\hline Maximum age & 10 & 10 & 11 & 9 & 12 \\
\hline Conditional natural mortality & $24 \%$ & $25 \%$ & $25 \%$ & $27 \%$ & $25 \%$ \\
\hline Conditional fishing mortality & 5 to $95 \%$ & & & & \\
\hline $\begin{array}{l}\log _{10}(\text { weight }): \log _{10}(\text { length }) \text { coefficients } \\
\text { (intercept; slope) }\end{array}$ & $-5.676 ; 3.303$ & $-5.879 ; 3.389$ & $-5.041 ; 3.053$ & $-5.680 ; 3.303$ & $-4.961 ; 3.016$ \\
\hline Age at sexual maturation & \multicolumn{5}{|c|}{4 years for all streams } \\
\hline $\begin{array}{l}\text { Fecundity-to-length relation } \\
\% \text { females }\end{array}$ & \multicolumn{5}{|c|}{$\begin{array}{l}\text { Intercept }=-2,456.349 \text { and slope }=18.803 \text { for all streams } \\
50 \% \text { for all ages }\end{array}$} \\
\hline$\%$ females spawning annually & \multicolumn{5}{|c|}{$50 \%$ for age 4 and $100 \%$ for all subsequent ages } \\
\hline Minimum length limits (TL) & $305 \mathrm{~mm}$ & $330 \mathrm{~mm}$ & $356 \mathrm{~mm}$ & $381 \mathrm{~mm}$ & $406 \mathrm{~mm}$ \\
\hline Total annual mortality (AM) & $51 \%$ & $60 \%$ & $53 \%$ & $49 \%$ & $55 \%$ \\
\hline
\end{tabular}

models between streams produced a variety of management implications for each population.

We show that Smallmouth Bass intergrade populations in larger Ozark streams can exhibit rapid or much slower growth. Growth ranged from relatively fast (i.e., the Black River) to relatively slow (i.e., the North Fork of the White River), evidenced by theoretical maximum lengths (Table 1) and mean length-at-age estimates (Table 2). These variations in growth could come as a result of a variety of biotic or abiotic factors. Smallmouth Bass are a unique sport fish, and are thought to naturally exhibit slow growth when compared with other Micropterus spp. (Beamesderfer and North 1995). Variable growth rates have been observed in Smallmouth Bass populations across the nation (Beamesderfer and North 1995) and in other streams in the Ozark regions of Missouri and Oklahoma (Lowry 1953; Fajen 1959, 1972; Covington 1982; Orth 1983; Reed and Rabeni 1989; Balkenbush and Fisher 1999). While each of the streams that we sampled have some similar characteristics (e.g., clear water, chert substrates, relatively cool water, low productivity, etc.), it is evident that there are other factors driving the variability in the dynamic rate functions and resulting management strategies for each of these populations.

Beamesderfer and North (1995) noted that in Smallmouth Bass populations, variability could be attributed to geographic, topographic, and other climatic features. Brewer etal. (2007) identified that Smallmouth Bass abundance in Ozark streams is correlated with specific geologic strata, substrate types, and groundwater influence. Dauwalter et al. (2007) also identified that Smallmouth Bass abundance in Oklahoma was correlated with stream morphology. With populations isolated in watersheds by geographic boundaries, variation in climate can play a role in the dynamic rates that describe these populations. We speculate that there may be more complex interactions affecting these populations. Factors such as warmwater influence, spring influence, reservoir connectivity, and interspecific competition may affect the populations that we sampled. Thermal refuge has been shown to be important to Smallmouth Bass in Ozark streams, especially in harsh winter temperatures (Westhoff et al. 2016).

In our study, growth seemed to have a positive relationship in streams containing high amounts of thermal refuge. The Black River flows south into Clearwater Lake, allowing Smallmouth Bass access to thermal refuge in the winter and warm summer months, evidenced by the fact that several tagged Smallmouth Bass were caught and reported from Clearwater Lake in winter months (Williamson et al. 2015). The East Fork of the Black River also has year-long warmwater influence from Tom Sauk Energy Center. Each of these factors could influence the growth rate of Smallmouth Bass on the Black River. Whitledge et al. (2002) found that the thermal requirement for optimum growth of Smallmouth Bass is $22^{\circ} \mathrm{C}$. The yearly average temperature on the Black River is nearly $16^{\circ} \mathrm{C}$, often reaching the thermal optimum temperature for Smallmouth Bass in summer months (USGS 2016). Warm temperatures and thermal refuge in the winter could help increase fish growth in the Black River. Whitledge et al. (2002) also found that Smallmouth Bass are subjected to mass mortality events if temperatures exceed $27^{\circ} \mathrm{C}$. The 


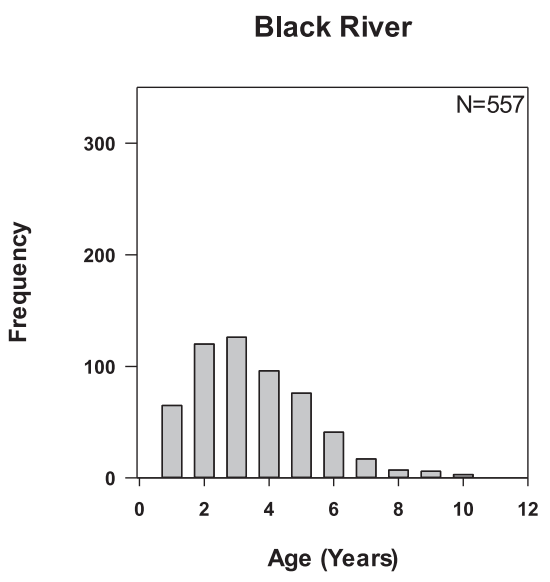

Current River

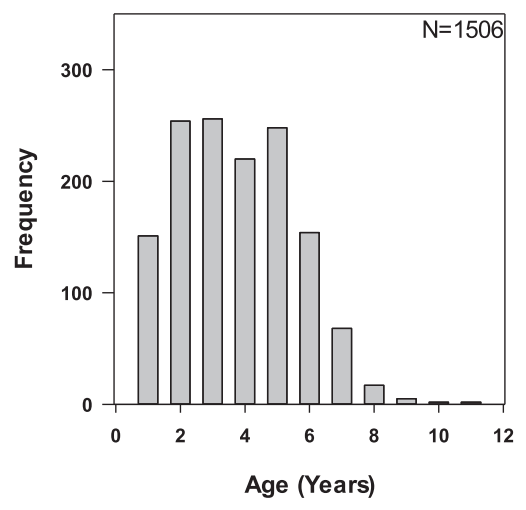

North Fork of the White River

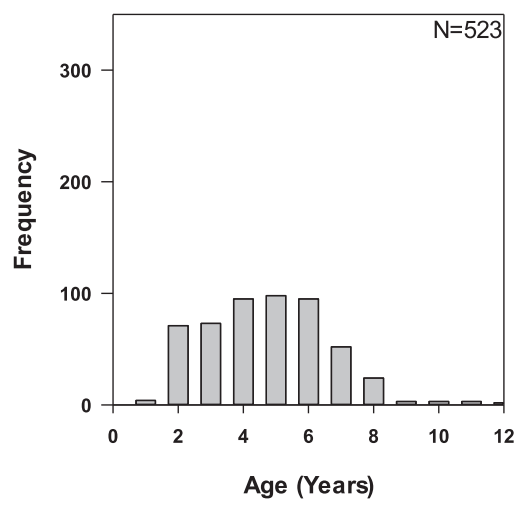

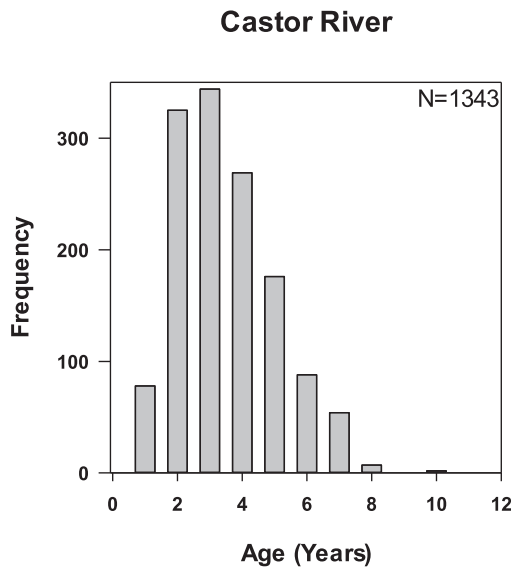

Courtois Creek

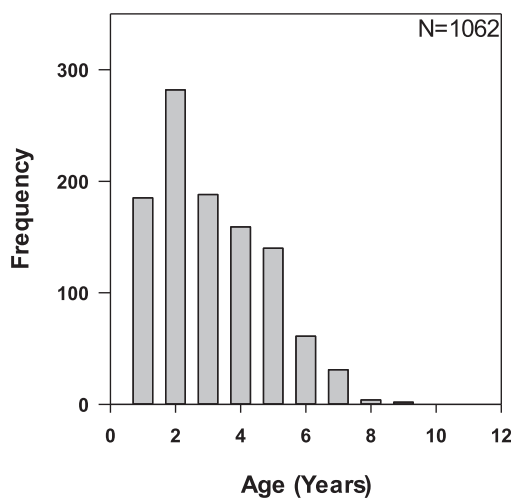

FIGURE 3. Smallmouth Bass age frequency distributions from back-calculated length-at-age estimates paired with electrofishing data from 20112013 on each study stream.

Black River only reaches these temperatures in warm summer months (USGS 2016), but even so, this species can seek thermal refuge in Clearwater Lake. Brewer and Rabeni (2011) also noted that young-of-the-year Smallmouth Bass in Ozark streams can actually benefit from high temperatures around $29^{\circ} \mathrm{C}$. Warmwater influence and reservoir influence during thermal extremes could contribute to the increased growth that we observed in the Black River Smallmouth Bass population. We observed relatively slow growth on the North Fork of the White River. There are high amounts of coldwater spring influence at the lower end of the North Fork of the White River, which sustains year-round temperatures of less than $21^{\circ} \mathrm{C}$ (Miller and Wilkerson 2001) and never reaches 
TABLE 2. The mean TL ( $\mathrm{mm})$ of Smallmouth Bass at various age estimates for each study stream. Fish were captured via traditional angling methods. The dashes denote that no individuals of that age were analyzed in our study.

\begin{tabular}{|c|c|c|c|c|c|}
\hline $\begin{array}{l}\text { Age } \\
\text { (years) }\end{array}$ & $\begin{array}{l}\text { Black } \\
\text { River }\end{array}$ & $\begin{array}{l}\text { Castor } \\
\text { River }\end{array}$ & $\begin{array}{c}\text { Courtois } \\
\text { Creek }\end{array}$ & $\begin{array}{c}\text { Current } \\
\text { River }\end{array}$ & $\begin{array}{l}\text { North } \\
\text { Fork of } \\
\text { the White } \\
\text { River }\end{array}$ \\
\hline 1 & 156.4 & 130.9 & 146.0 & 163.8 & 103.5 \\
\hline 2 & 221.1 & 188.9 & 214.0 & 214.3 & 173.3 \\
\hline 3 & 268.5 & 237.4 & 264.3 & 274.2 & 223.6 \\
\hline 4 & 306.5 & 282.7 & 311.8 & 310.0 & 264.9 \\
\hline 5 & 354.3 & 321.8 & 351.3 & 342.5 & 296.0 \\
\hline 6 & 388.6 & 361.9 & 384.3 & 366.3 & 327.2 \\
\hline 7 & 417.5 & 381.7 & 422.1 & 381.6 & 361.9 \\
\hline 8 & 457.2 & 391.2 & 445.8 & 413.3 & 388.8 \\
\hline 9 & 469.1 & - & 462.3 & 429.3 & 416.6 \\
\hline 10 & 487.7 & 473.7 & - & 454.7 & 432.7 \\
\hline 11 & - & - & - & 474.9 & 444.5 \\
\hline 12 & - & - & - & - & 455.9 \\
\hline
\end{tabular}

thermal optimum growth for adult or young-of-the-year Smallmouth Bass. The lower sections of the North Fork of the White River are inhabited by nonnative Rainbow Trout Oncorhynchus mykiss and Brown Trout Salmo trutta. Interspecific competition has been observed between Smallmouth Bass, trout species, and other predatory fish species (Metcalf et al. 1997; Wuellner et al. 2011). Coldwater influence paired with competition between two predatory fish species could inhibit Smallmouth Bass growth rates on the North Fork of the White River as well. Although we observed decreased growth in one particularly cold stream, spring influence has been shown to have a positive effect on Smallmouth Bass growth rates.

Whitledge et al. (2002) observed increased Smallmouth Bass growth rates in streams with spring influence, which facilitated thermal refuge in harsh summer and winter months. Spring-fed systems also provide warmwater refuge for the overwintering survival of young-of-the-year Smallmouth Bass (Peterson and Rabeni 1996). Warmwater streams with spring influence may exhibit increased growth rates relative to what we observed in the North Fork of the White River. It is also noteworthy that growth variation has been demonstrated between genetically distinct sport fish populations (Kleinsasser et al. 1990). The Ozark region of Missouri is home to intergrade populations of the Northern Smallmouth Bass and Neosho Smallmouth Bass subspecies (Stark and Echelle 1998). Further investigation would be necessary to determine if genetic variation played any role in the variable growth that was observed. Regardless of the factors that triggered the variable growth between populations, the variability did affect the management implications.

Evaluations of the current 305-mm MLL in Missouri's Ozark streams revealed that trophy potential for some Smallmouth Bass populations in Ozark streams could increase with more restrictive MLLs. Exploitation estimates greater than $25 \%$ were reported for these study streams, along with capture rates greater than $60 \%$ (Williamson et al. 2015). These exploitation rates are similar to those seen in other common sport fisheries (Allen etal. 1998; Miranda etal. 2002). Taking exploitation estimates into consideration, the Black River is the only stream that could currently be in danger of growth overfishing according to our YPR models. The models of the Black River population showed that the highest yield could be produced from a $355-\mathrm{mm}$ or a $381-\mathrm{mm}$ MLL. The SPR models revealed that the Black River may also be in danger of recruitment overfishing, and that a more restrictive MLL would provide higher reproductive potential. Although the Black River was the only stream currently in danger of recruitment and growth overfishing, our models for memorable-sized Smallmouth Bass revealed that every population could respond positively to a more restrictive MLL (with the exception of the North Fork of the White River). Depending on the management goal (i.e., either increased angler yield or increased trophy potential), these streams would likely respond positively to more restrictive MLLs. However, these models are density independent and could be excluding the possibility of intraspecific competition. Wilde (1997) found that Largemouth Bass Micropterus salmoides size structure did not always increase with a more restrictive length limit, but angler catch rates usually increased. Other Midwestern bodies of water have exhibited increased size structures with more restrictive regulations. Paragamian (1984) found that a $305-\mathrm{mm}$ MLL improved the size structure of a Smallmouth Bass population on the Maquoketa River in Iowa. Lyons et al. (1996) found that a 356-mm MLL improved Smallmouth Bass size structure in some Wisconsin streams, but this author did report data from other studies that showed negative effects from a more restrictive MLL. Finally, Newman and Hoff (2000) observed increased size structure of Smallmouth Bass in Pallette Lake, Wisconsin, after implementing a 406-mm MLL.

These results can help inform Smallmouth Bass management strategies in the Ozark streams of Missouri and throughout the Ozark range of the Midwest. Black bass are popular sport fishes throughout the United States (USFWS 2011). Improving or maintaining size structure of black bass fisheries is often a priority for managers (Dotson et al. 2013). Often, the most effective way to ensure that a population of fish is meeting its growth potential is to minimize fishing mortality (Crawford et al. 2002; Dotson et al. 2013). Although there are many ways 


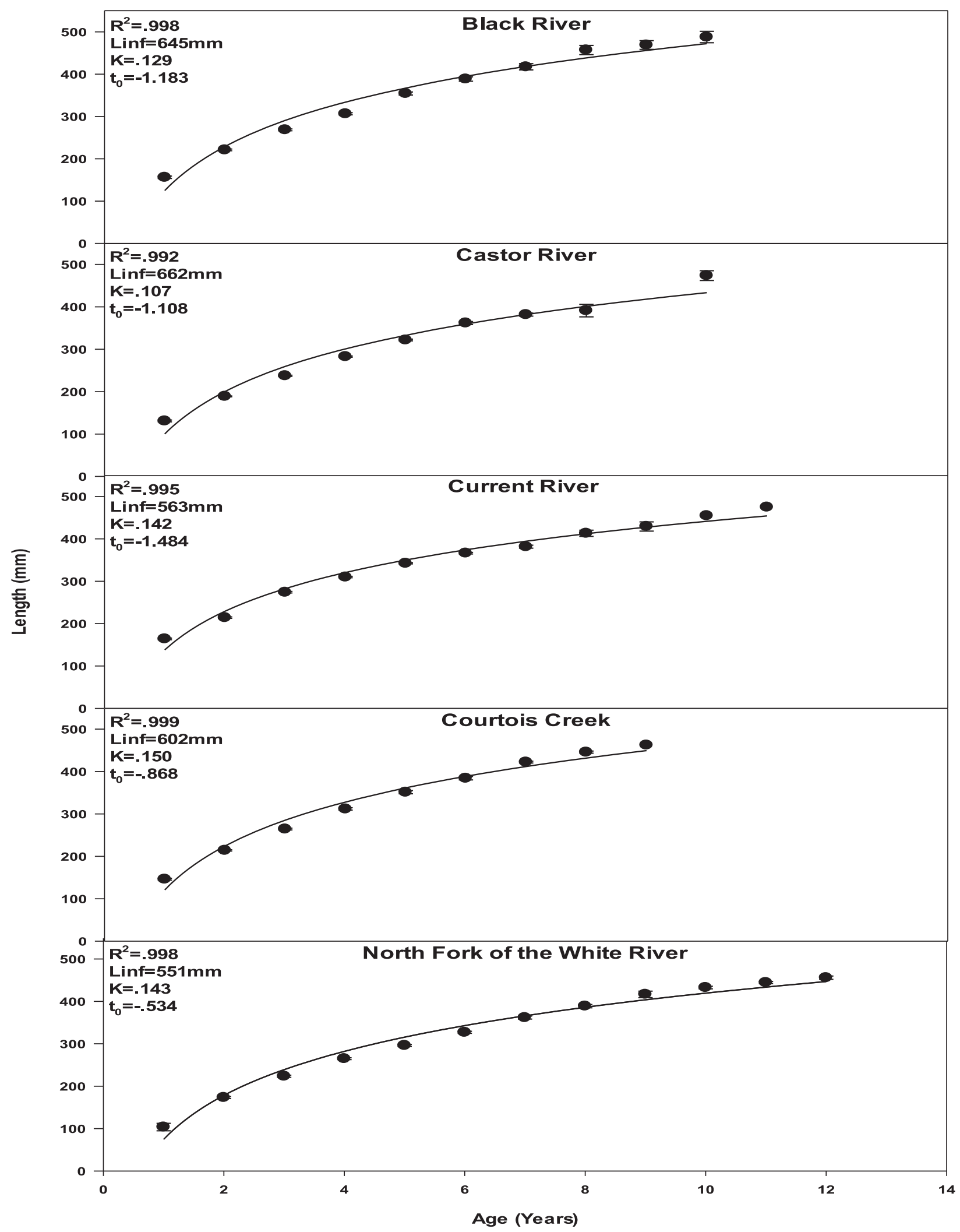

FIGURE 4. von Bertalanffy growth curves for each stream; Linf is the theoretical maximum length, $K$ is the Brody growth coefficient, and $t_{0}$ is the theoretical length at time 0 . 


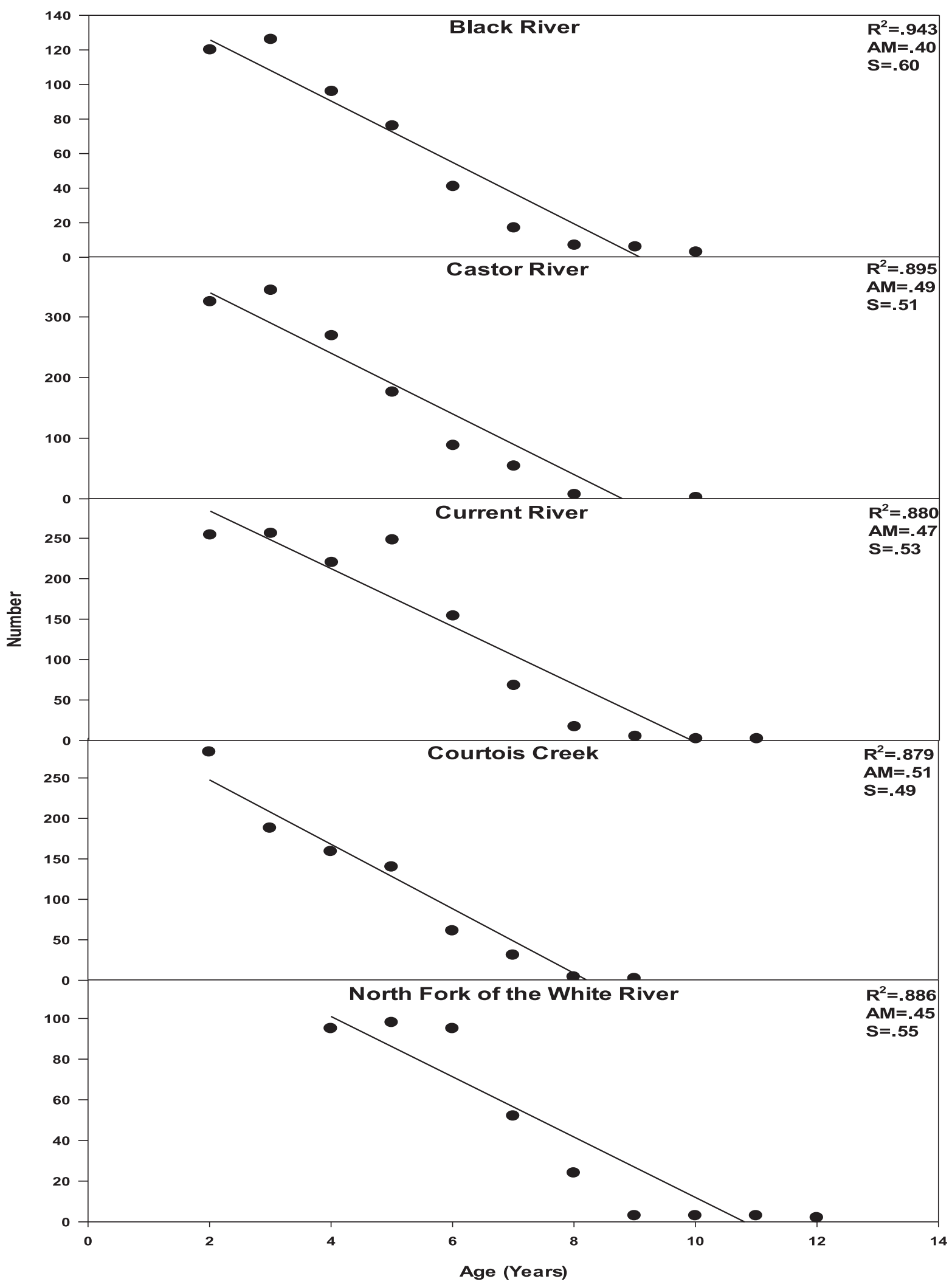

FIGURE 5. Catch curves mortality estimates for each stream; AM is the total annual mortality and $\mathrm{S}$ is the total annual survival. 

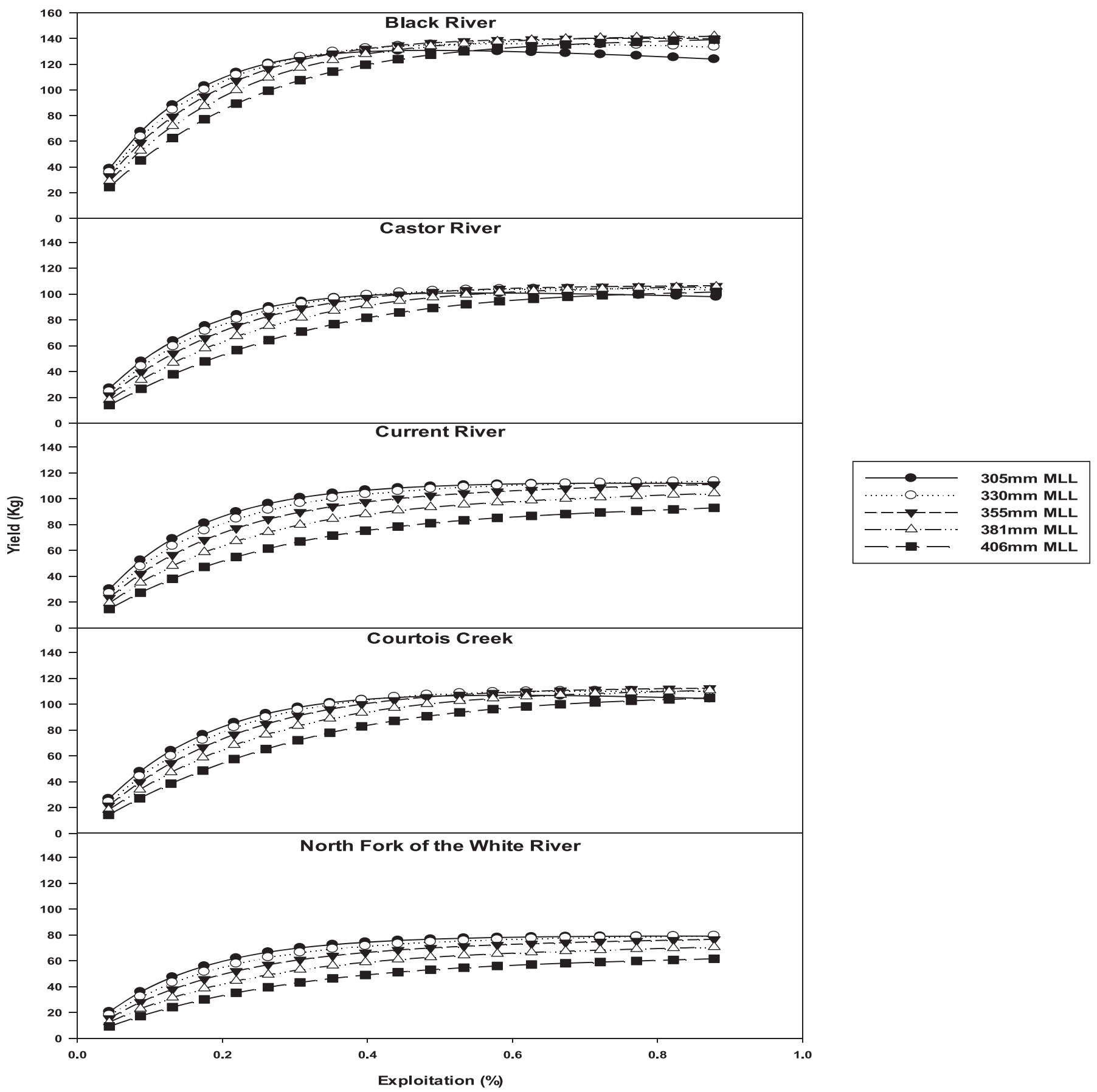

FIGURE 6. Yield-per-recruit models for each sample stream. The models were built using theoretical cohorts of 1,000 fish.

of minimizing fishing mortality (e.g., closed seasons, catch-and-release regulations, slot limits), our models show that in these Ozark stream populations, Smallmouth Bass size distributions could respond positively to more restrictive length limits. There is already a closed season for Smallmouth Bass in Missouri's Ozark streams to protect the spawning period. Additional restrictive length limits may provide increased angler yield and improved size structure in these populations. Likewise, conservative length limits could increase reproductive potential on each stream. When considering the anglers that utilize these fisheries, increasing length limits on these streams could provide higher angler yield and more trophy fishing opportunities in areas that were not historically known for trophy Smallmouth Bass fishing. 

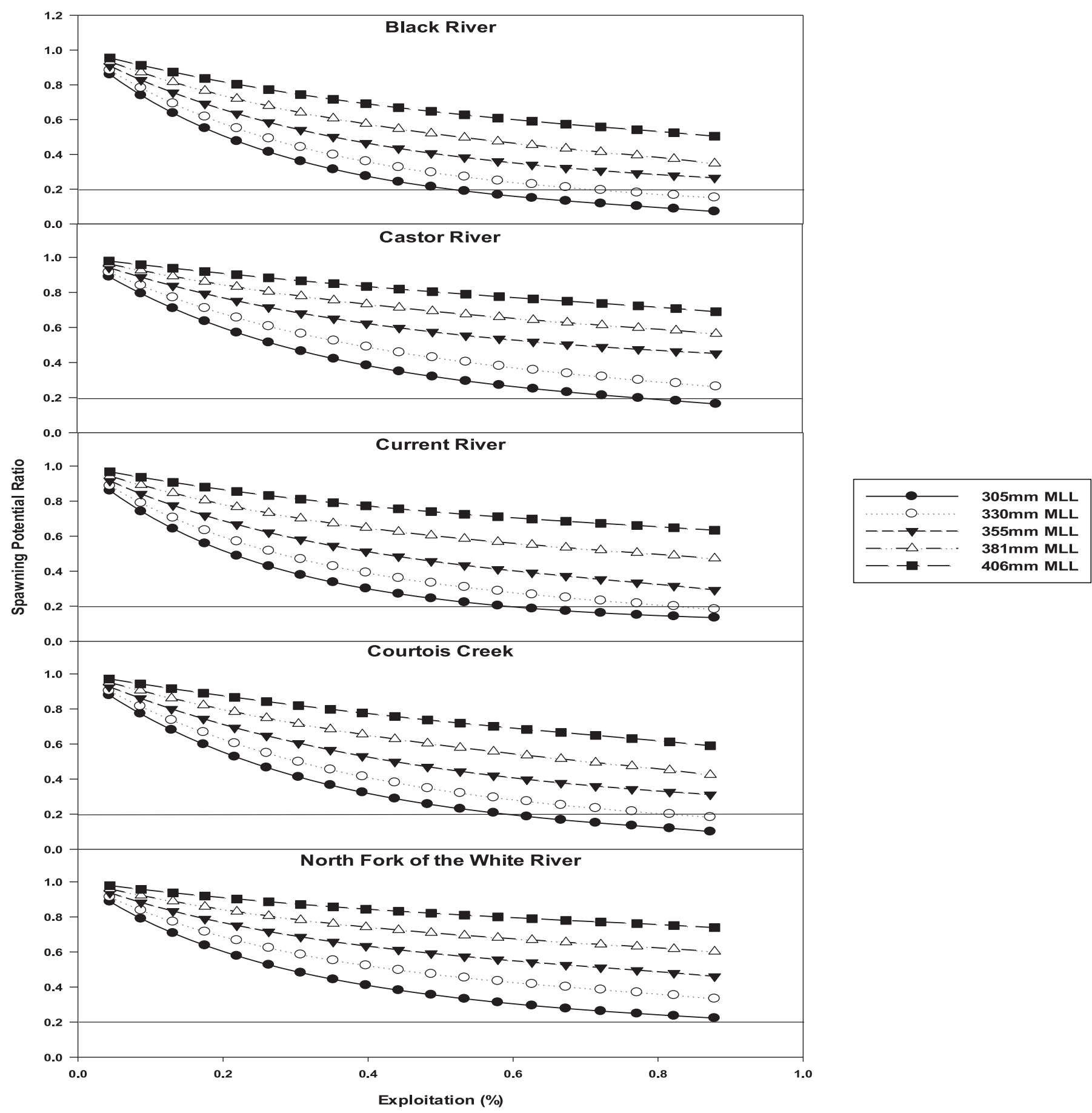

FIGURE 7. Spawning-potential-ratio models for each sample stream. The horizontal line at $20 \%$ SPR marks the threshold for sustainable reproduction.

Estimates of recruitment, growth, and mortality on each of these streams provide novel data for five populations of Smallmouth Bass in Ozark streams. Future studies should monitor these dynamic rate functions to ensure the sustainability and potential of these particular fisheries. Also, more research is necessary to elucidate the variables responsible for the differing growth observed within these populations. Dynamic rate estimates remain a crucial component of fisheries management, and proper estimates of recruitment, growth, and mortality will help researchers provide best management strategies to ensure the success of Smallmouth Bass populations throughout Midwestern Ozark streams. 

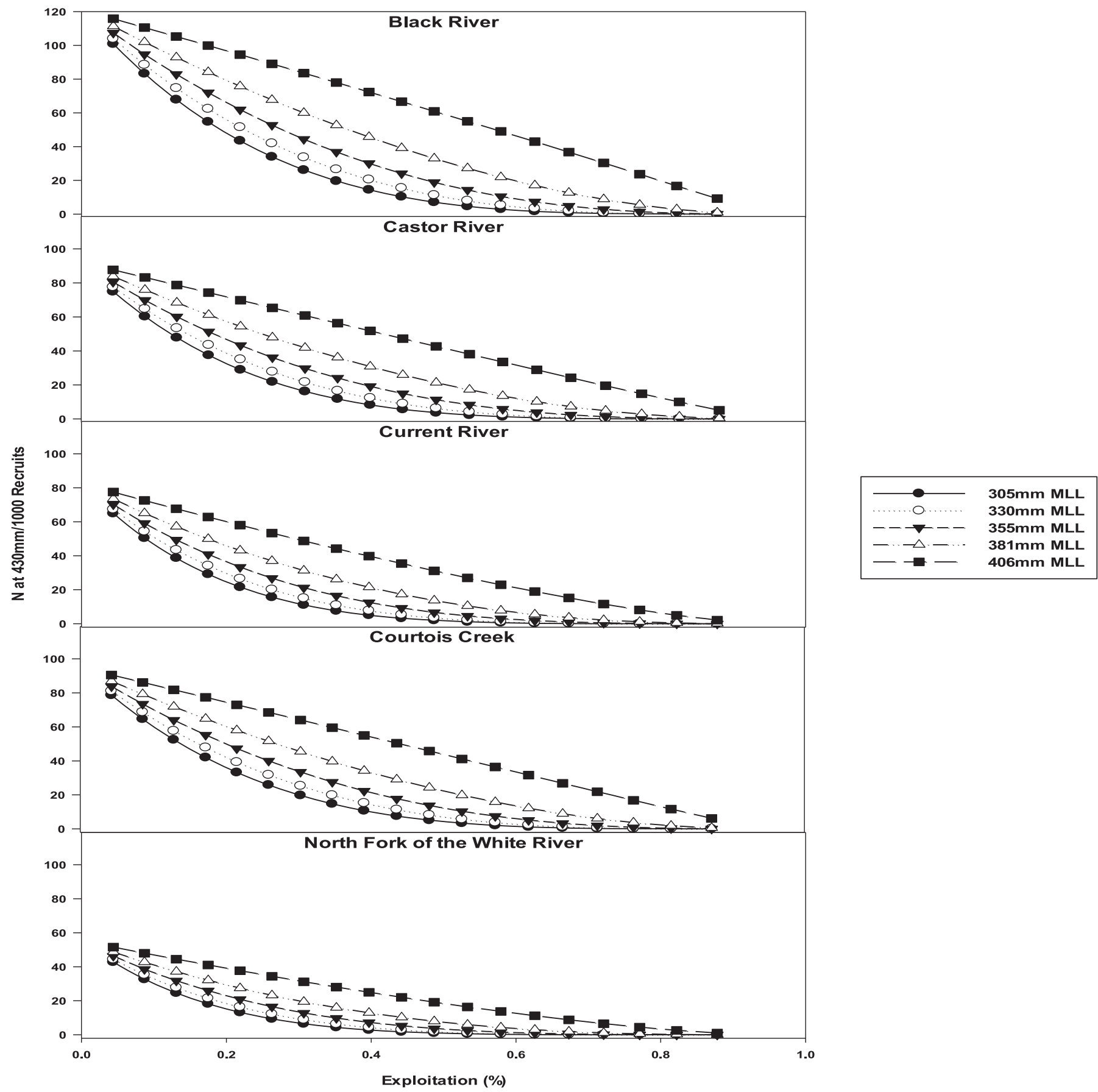

FIGURE 8. The number of memorable-sized (430-mm) Smallmouth Bass under varying MLLSs on each stream. The models were built using theoretical cohorts of 1,000 fish

\section{ACKNOWLEDGMENTS}

This study was made possible by the hard work of W. Sleeper, T. Devine, and J. Abner. We also thank the Missouri Department of Conservation for their assistance. There is no conflict of interest declared in this article.

\section{REFERENCES}

Allen, M. S., L. E. Miranda, and R. E. Brock. 1998. Implications of compensatory and additive mortality to the management of selected sportfish populations. Lakes and Reservoirs: Research and Management 3:67-79.

Balkenbush, P. E., and W. L. Fisher. 1999. Population characteristics and management of black bass in eastern Oklahoma streams. 
Proceedings of the Annual Conference Southeastern Association of Fish and Wildlife Agencies 53:130-143.

Beamesderfer, R. C., and J. A. North. 1995. Growth, natural mortality, and predicted response to fishing for Largemouth Bass and Smallmouth Bass populations in North America. North American Journal of Fisheries Management 15:688-704.

Beverton, R. J. H., and S. J. Holt. 1957. On the dynamics of exploited fish populations. UK Ministry of Agriculture, Food and Fisheries Investigations 2, London.

Blanc, T., M. Caldwell, and M. Hawks. 1998. Meramec River watershed demonstration project. Missouri Department of Conservation, Jefferson City.

Brewer, S. K., and J. M. Long. 2015. Biology and ecology of Neosho Smallmouth Bass and the genetically distinct Ouachita lineage. Pages 281-296 in M. D. Tringali, J. M. Long, T. W. Birdsong, and M. S. Allen, editors. Black bass diversity: multidisciplinary science for conservation. American Fisheries Society, Symposium 82, Bethesda, Maryland.

Brewer, S. K., and D. J. Orth. 2015. Smallmouth Bass Micropterus dolomieu Lacepede, 1802. Pages 9-26 in M. D. Tringali, J. M. Long, T. W. Birdsong, and M. S. Allen, editors. Black bass diversity: multidisciplinary science for conservation. American Fisheries Society, Symposium 82, Bethesda, Maryland.

Brewer, S. K., and C. F. Rabeni. 2011. Interactions between naturaloccurring landscape conditions and land use influencing the abundance of riverine Smallmouth Bass, Micropterus dolomieu. Canadian Journal of Fisheries and Aquatic Sciences 68:1922-1933.

Brewer, S. K., C. F. Rabeni, S. P. Sowa, and G. Annis. 2007. Natural landscape and stream segment attributes influencing the distribution and relative abundance of riverine Smallmouth Bass in Missouri. North American Journal of Fisheries Management 27:326-341.

Buckmeier, D. L., and R. G. Howells. 2003. Validation of otoliths for estimating ages of Largemouth Bass to 16 years. North American Journal of Fisheries Management 23:590-593.

Bueltmann, A. T., and Q. E. Phelps. 2015. Assessment of the middle Mississippi River Channel Catfish population. Copeia 2015:580-585.

Chambers, R. C., and E. A. Trippel. 1997. Early life history and recruitment in fish populations. Chapman and Hall, New York.

Chapman, D. G., and D. S. Robson. 1960. The analysis of a catch curve. Biometrics [online serial] 16:354.

Cieslewicz, P. 2004. Black River watershed inventory and assessment. Missouri Department of Conservation, Jefferson City.

Colombo, R. E., J. E. Garvey, N. D. Jackson, R. Brooks, D. P. Herzog, R. A. Hrabik, and T. W. Spier. 2007. Harvest of Mississippi River sturgeon drives abundance and reproductive success: a harbinger of collapse? Journal of Applied Ichthyology 23:444-451.

Cooke, S., and D. P. Philipp. 2009. Centrarchid fishes: diversity, biology, and conservation. Wiley-Blackwell, Hoboken, New Jersey.

Covington, W. G. 1982. Smallmouth Bass populations in the Ozark National Scenic Riverways. Doctoral dissertation. University of Missouri, Columbia.

Crawford, S., W. F. Porak, D. J. Renfro, and R. L. Calteux. 2002. Characteristics of trophy Largemouth Bass populations in Florida. Pages 567-581 in D. P. Philipp, and M. S. Ridgeway, editors. Black bass: ecology, conservation, and management. American Fisheries Society, Symposium 31, Bethesda, Maryland.

Dauwalter, D. C., D. K. Splinter, W. L. Fisher, and R. A. Marston. 2007. Geomorphology and stream habitat relationships with Smallmouth Bass (Micropterus dolomieu) abundance at multiple spatial scales in eastern Oklahoma. Canadian Journal of Fisheries and Aquatic Sciences 64:1116-1129.

DeVries, D. R., and R. V. Frie. 1996. Determination of age and growth. Pages 488-512 in B. R. Murphy and D. W. Willis, editors. Fisheries techniques, 2nd edition. American Fisheries Society, Bethesda, Maryland.
Dotson, J. R., M. S. Allen, W. E. Johnson, and J. Benton. 2009. Impacts of commercial gill-net bycatch and recreational fishing on a Florida Black Crappie population. North American Journal of Fisheries Management 29:1454-1465.

Dotson, J. R., M. S. Allen, J. A. Kerns, and W. F. Pouder. 2013. Utility of restrictive harvest regulations for trophy Largemouth Bass management. North American Journal of Fisheries Management 33:499-507.

Fajen, O. F. 1959. Movement and growth of Smallmouth Bass in small Ozark streams. Doctoral dissertation. University of Missouri-Columbia, Columbia.

Fajen, O. F. 1972. The standing crop of fishes in Courtois Creek, Missouri. Missouri Department of Conservation, Federal Aid in Fish Restoration, Project FIR-20, Columbia.

Frie, R. V. 1982. Measurement of fish scales and back calculation of body lengths using a digitizing pad and microcomputer. Fisheries 7 (5):5-8.

Funk, J. L., and G. G. Fleener. 1974. The fishery of a Missouri Ozark stream, Big Piney River, and the effects of stocking fingerling Smallmouth Bass. Transactions of the American Fisheries Society 103:757771 .

Goodyear, C. P. 1993. Spawning stock biomass per recruit in fisheries management: foundation and current use. Canadian Special Publication of Fisheries and Aquatic Sciences 120:67-81.

Graham, R. J., and D. J. Orth. 1986. Effects of temperature and streamflow on time and duration of spawning by Smallmouth Bass. Transactions of the American Fisheries Society 115:693-702.

Guy, C. S., and D. W. Willis. 1995. Population characteristics of Black Crappies in South Dakota waters: a case for ecosystem-specific management. North American Journal of Fisheries Management 15:754 765.

Hales, L. S., and M. C. Belk. 1992. Validation of otolith annuli of Bluegills in a southeastern thermal reservoir. Transactions of the American Fisheries Society 121:823-830.

Hammers, B. E., and L. E. Miranda. 1991. Comparison of methods for estimating age, growth, and related population characteristics of White Crappies. North American Journal of Fisheries Management 11:492-498.

Heidinger, R. C., and K. Clodfelter. 1987. Validity of the otolith for determining age and growth of Walleye, Striped Bass, and Smallmouth Bass in power plant cooling ponds. Pages 241-251 in R. C. Summerfelt and G. E. Hall, editors. Age and growth of fish. Iowa State University Press, Ames.

Hubert, W. A., and M. C. Quist. 2010. Inland fisheries management in North America. American Fisheries Society, Bethesda, Maryland.

Isermann, D. A., W. L. Mckibben, and D. W. Willis. 2002. An analysis of methods for quantifying crappie recruitment variability. North American Journal of Fiheries Management 22:1124-1135.

Jacobson, R. B., and K. B. Gran. 1999. Gravel sediment routing from widespread, low-intensity landscape disturbance, Current River basin, Missouri. Earth Surface Processes and Landforms 24:897-917.

Kleinsasser, L. J., J. H. Williamson, and B. G. Whiteside. 1990. Growth and catchability of northern, Florida, and F, hybrid Largemouth Bass in Texas ponds. North American Journal of Fisheries Management 10:462-468.

Lohman, K., J. R. Jones, and C. Baysinger-Daniel. 1991. Experimental evidence for nitrogen limitation in a northern Ozark stream. Journal of the North American Benthological Society 10:14-23.

Long, J. M., and W. L. Fisher. 2001. Precision and bias of Largemouth, Smallmouth, and Spotted Bass ages estimated from scales, whole otoliths, and sectioned otoliths. North American Journal of Fisheries Management 21:636-645.

Lowry, F. M. 1953. The growth of the Smallmouth Bass (Micropterus dolomieui) in certain Ozark streams. Doctoral dissertation. University of Missouri, Columbia. 
Lyons, J., P. D. Kanehl, and D. M. Day. 1996. Evaluation of a 356-mm minimum-length limit for Smallmouth Bass in Wisconsin streams. North American Journal of Fisheries Management 16:952-957.

MacCrimmon, H. R., and W. H. Robbins. 1975. Distribution of the black basses in North America. Pages 56-66 in H. Clepper, editor. Black bass biology and management. Sport Fishing Institute, Washington, D.C.

Maceina, M. J. 1997. Simple application of using residuals from catchcurve regressions to assess year-class strength in fish. Fisheries Research 32:115-121.

Maceina, M. J., and S. M. Sammons. 2006. An evaluation of different structures to age freshwater fish from a northeastern US river. Fisheries Management and Ecology 13:237-242.

Matthews, W. J. 1982. Small fish community structure in Ozark streams: structured assembly patterns or random abundance of species? American Midland Naturalist 107:42-54.

Metcalf, C., F. Pezold, and B. G. Crump. 1997. Food habits of introduced Rainbow Trout (Oncorhynchus mykiss) in the upper Little Missouri River drainage of Arkansas. Southwestern Naturalist 42:148-154.

Miller, S. M., and T. F. Wilkerson. 2001. North Fork of the White River (Missouri) watershed inventory and assessment. Missouri Department of Conservation, Jefferson City.

Miranda, L. E., R. E. Brock, and B. S. Dorr. 2002. Uncertainty of exploitation estimates made from tag returns. North American Journal of Fisheries Management 22:1358-1363.

Newman, S. P., and M. H. Hoff. 2000. Evaluation of a 16-inch minimum length limit for Smallmouth Bass in Pallette Lake, Wisconsin. North American Journal of Fisheries Management 20:90-99.

Norman, D. E. 1994. Headwater diversion channel watershed inventory and assessment. Missouri Department of Conservation, Jefferson City.

Orth, D. J. 1983. Population characteristics of Smallmouth Bass in Glover Creek, southeast Oklahoma. Proceedings of the Oklahoma Academy of Science 63:37-41.

Paragamian, V. L. 1984. Evaluation of a 12.0-inch minimum length limit on Smallmouth Bass in the Maquoketa River, Iowa. North American Journal of Fisheries Management 4:507-513.

Peterson, J. T., and C. F. Rabeni. 1996. Natural thermal refugia for temperate warmwater stream fishes. North American Journal of Fisheries Management 16:738-746.

Pflieger, W. L. 1966. Reproduction of the Smallmouth Bass (Micropterus dolomieui) in a small Ozark stream. American Midland Naturalist 76:410-418.

Pflieger, W. L. 1971. A distributional study of Missouri fishes. Publication of the University of Kansas Museum of Natural History 20:225570.

Pollock, K. H., J. M. Hoenig, W. S. Hearn, and B. Calingaert. 2001. Tag reporting rate estimation: 1 . An evaluation of the high-reward tagging method. North American Journal of Fisheries Management 21:521-532.

Prather, E. E. 1967. A note on the accuracy of the scale method in determining the ages of Largemouth Bass and Bluegill from Alabama waters. Proceedings of the Annual Conference Southeastern Association of Game and Fish Commissioners 20:483-486.

Probst, W. E., C. F. Rabeni, W. G. Covington, and R. E. Marteney. 1984. Resource use by stream-dwelling Rock Bass and Smallmouth Bass. Transactions of the American Fisheries Society 113:283-294.

Reed, M. S., and C. F. Rabeni. 1989. Characteristics of an unexploited Smallmouth Bass population in a Missouri Ozark stream. North American Journal of Fisheries Management 9:420-426.

Ricker, W. E. 1973. Linear regressions in fishery research. Journal of the Fisheries Research Board of Canada 30:409-434.
Robson, D. S., and D. G. Chapman. 1961. Catch curves and mortality rates. Transactions of the American Fisheries Society 90:181-189.

Rude, N. P., W. D. Hintz, J. D. Norman, K. L. Kanczuzewski, A. J. Yung, K. D. Hofer, and G. W. Whitledge. 2013. Using pectoral fin rays as a non-lethal aging structure for Smallmouth Bass: precision with otolith age estimates and the importance of reader experience. Journal of Freshwater Ecology 28:199-210.

Sissenwine, M. P. 1984. Why do fish populations vary? Pages 59-94 in R. M. May, editor. Exploitation of marine communities. Springer, Berlin.

Slipke, J. W., and M. J. Maceina. 2014. Fishery analysis and modeling simulator (FAMS), version 1.64. American Fisheries Society, Bethesda, Maryland.

Slipke, J. W., A. D. Martin, J. Pitlo, and M. J. Maceina. 2002. Use of the spawning potential ratio for the upper Mississippi River Channel Catfish fishery. North American Journal of Fisheries Management 22:1295-1300.

Stark, W. J., and A. A. Echelle. 1998. Genetic structure and systematics of Smallmouth Bass, with emphasis on interior highlands populations. Transactions of the American Fisheries Society 127:393-416.

Taubert, B. D., and J. A. Tranquilli. 1982. Verification of the formation of annuli in otoliths of Largemouth Bass. Transactions of the American Fisheries Society 111:531-534.

USFWS (U.S. Fish and Wildlife Service). 2011 National survey of fishing, hunting, and wildlife-associated recreation. Available: https:// www.census.gov/prod/2012pubs/fhw11-nat.pdf. (September 2019).

USGS (U.S. Geological Survey). 2016. National weather information data available on the World Wide Web (USGS water data for the nation). Available: https://waterdata.usgs.gov/nwis/. (May 2019).

Von Bertalanffy, L. 1938. A quantitative theory of organic growth (inquiries on growth laws. II). Human Biology 10:181-213.

Wahl, N., Q. E. Phelps, J. E. Garvey, S. T. Lynott, and W. E. Adams. 2009. Comparison of scales and sagittal otoliths to back-calculate lengths-at-age of crappies collected from Midwestern waters. Journal of Freshwater Ecology 24:469-475.

Weisberg, S. 1986. A linear model approach to backcalculation of fish length. Journal of the American Statistical Association 81:922-929.

Westhoff, J. T., C. Paukert, S. Ettinger-Dietzel, H. Dodd, and M. Siepker. 2016. Behavioural thermoregulation and bioenergetics of riverine Smallmouth Bass associated with ambient cold-period thermal refuge. Ecology of Freshwater Fish 25:72-85.

Whitledge, G. W., R. S. Hayward, and C. F. Rabeni. 2002. Effects of temperature on specific daily metabolic demand and growth scope of sub-adult and adult Smallmouth Bass. Journal of Freshwater Ecology 17:353-361.

Whitledge, G. W., and C. F. Rabeni. 2002. Benthic community metabolism in three habitats in an Ozark stream. Hydrobiologia 437:165170.

Wilde, G. R. 1997. Largemouth Bass fishery responses to length limits. Fisheries 22(6):14-23.

Wilkerson, T. F. 2003. Current river watershed inventory and assessment. Missouri Department of Conservation, Jefferson City.

Williamson, C., N. Girondo, P. Cieslewicz, S. Peper, D. Knuth, M. Reed, J. Ackerson, A. J. Pratt, and J. Girondo. 2015. Harvest evaluation of Smallmouth Bass from selected ozark streams. Missouri Department of Conservation, Jefferson City.

Wuellner, M. R., B. D. Graeb, D. W. Willis, B. J. Galster, T. M. Selch, and S. R. Chipps. 2011. Competitive interactions between Walleye (Sander vitreus) and Smallmouth Bass (Micropterus dolomieu) under various controlled conditions. Journal of Freshwater Ecology 26:299314 


\section{Appendix: Additional Data}

TABLE A.1. Smallmouth Bass length parameters on each study stream from the 2011-2013 electrofishing samples. Mean TLs (mm) are portrayed with SE values.

\begin{tabular}{lccccc}
\hline & Black River & Castor River & Courtois Creek & Current River & North Fork of the White River \\
\hline$N$ & 557 & 1,343 & 1,062 & 1,506 & 523 \\
Minimum TL & 76 & 81 & 74 & 58 & 89 \\
Maximum TL & 508 & 485 & 521 & 521 & 460 \\
Mean TL & $283 \pm 3.44$ & $255 \pm 1.91$ & $264 \pm 2.64$ & $300 \pm 2.15$ & $282 \pm 3.08$ \\
\hline
\end{tabular}

TABLE A.2. Smallmouth Bass length and age parameters on each study stream from the 2016-2017 angling samples. Mean TLs (mm) are portrayed with SE values.

\begin{tabular}{lccccc}
\hline & Black River & Castor River & Courtois Creek & Current River & North Fork of the White River \\
\hline$N$ & 74 & 75 & 67 & 75 & 76 \\
Minimum TL & 305 & 305 & 305 & 305 & 305 \\
Maximum TL & 471 & 445 & 455 & 457 & 450 \\
Mean TL & $346 \pm 4.9$ & $336 \pm 3.55$ & $342 \pm 4.60$ & $338 \pm 4.47$ & $340 \pm 4.07$ \\
Minimum age & 3 & 3 & 2 & 2 & 4 \\
Maximum age & 10 & 10 & 9 & 11 & 12 \\
\hline
\end{tabular}

